Вісник Дніпропетровського університету. Серія: геологія, географія. 2016. 24 (1), 71-82.

Vìsnik Dnìpropetrovs'kogo unìversitetu. Serìâ geologîa, geographìâ

Dnipropetrovsk University Bulletin. Series geology, geography. 2016, 24 (1), 71-82.

doi: $10.15421 / 111611$

http://geology-dnu.dp.ua

UDC 502.64:502.43(477.54)

\title{
Geological heritage as an integral part of the Nature Reserve Lands of Kharkiv oblast
}

\author{
V.V. Manyuk \\ Oles Honchar Dnipropetrovsk National University, e-mail: manuk-geo@mail.ru
}

\begin{abstract}
The paper looks at the structural tectonic location of Kharkiv oblast, its geological and geomorphological structure, which form the underlying features of nature's variety and beauty, the development of the Nature Reserve Lands (NRL) of the region, the rich potential of the region's natural complexes and objects, which have conservation, scientific, aesthetic, recreational and other values. It is shown that Kharkiv oblast, despite having a smaller area under the NRL than most other oblasts of Ukraine, has in fact great prospects for expansion in this respect, and also for improving the structure of the qualitative and quantitative distribution of Nature Reserve Lands objects. We analyzed the results of implementing the programme of forming an ecological network for the oblast and we emphasize the integral connection of biological and geological diversity. The protection of both the biological and geological elements is the path to stable development. We determined the historical preconditions for the necessity of preserving both inanimate nature and wildlife, beginning with the establishment in 1910 of the Khortytske Society for Nature Protection, the first such organization in Russia, to Ukraine's joining the European Association for the Conservation of the Geological Heritage (ProGEO) in 1997. We evaluated the existing potential of the objects of geological heritage, had they been included in the NRL, the level of protection would have been extended and improved. For the first time, we provide a listing of the geological monuments of Kharkiv oblast, taking maximum account of the results of a revision of research, which was conducted in 2003-2004; and further monitoring and research, which was conducted in different years by scientists of $V$. N. Karazin Kharkiv National University for compiling a list of the geological heritage of the region. We identified the objects of geological heritage which have lost their significance as valuable objects of geological heritage due to natural and technological factors and thus should be excluded from the register. We determined the most valuable geosites, worthy of being included in the General European Register of Geological Heritage according to the criteria developed for the international project GEOSITES.
\end{abstract}

Key words: geosite, geodiversity, ecological network, monitoring, geology

\section{Геологічна спадщина, як невід’ємний елемент природно-заповідного фонду Харківської області}

\section{В.В. Манюк}

Дніпропетровський національний університет імені Олеся Гончара, е-таil: manuk-geо@таil.ru

Розглянуто особливості структурно-тектонічного положення Харківської області, геологічної і геоморфологічної будови, сукупністю яких визначені головні риси різноманіття і краси природи, формування природно-заповідного фонду (ПЗФ) регіону, зумовлений потужний потенціал природних комплексів і об'сктів, що мають особливі природоохоронну, наукову, естетичну, рекреаційну та інші цінності. Встановлено, що Харківська область попри те, що посідас передостаннс місце в Україні за питомою вагою площі ПЗФ, насправді має надзвичайно великі перспективи щодо суттсвого їх збільшення та вдосконалення структури якісного і кількісного розподілу об'єктів природно-заповідного фонду. Проаналізовано результати виконання програми формування екологічної мережі області та зазначено невід'смність зв'язку біо- $\mathbf{i}$ георізноманіття, охорона яких є шляхом до сталого розвитку. Визначені історичні передумови необхідності збереження неживої природи в Україні так само, як і живої, від створення у 1910 р. першого в Росії Хортицького товариства охорони природи до прийняття е 1997 р. України в члени Європейської асоціації зі збереження геологічної спадщини (РrоGEO). Оцінений дійсний потенціал об'єктів геологічної спадщини, включення яких до ПЗФ області суттсво розширить $\mathrm{i}$ покращить рівень заповідання. Вперше надасться узагальнений список геологічних пам'яток природи Харківської області з максимальним урахуванням результатів ревізійного обстеження, проведеного у 2003-2004 роках, подальшого моніторингу та досліджень різних років, здійснених науковцями Харківського національного університету ім. Каразіна і спрямованих на інвентаризацію геологічної спадщини регіону. Встановлено перелік геологічних пам'яток, 
які втратили своє значення, як цінні об'єкти геологічної спадщини через природні і техногенні чинники і мають бути виключені з перспективних ресстрів. Визначені найбільш ціні геосайти, гідні включення до загальноєвропейського реєстру геологічної спадщини у відповідності із критеріями, розробленими для міжнародного проекту ГЕОСАЙТИ.

Ключові слова: геосайт, георізноманіття, екологічна мережа, моніторинг, геологія

Introduction. Kharkiv oblast is situated in the water shed of the Siverskyi Donets river and only in the south is its landscape formed by the nearest tributaries of rivers Orel and Samara. From a geomorphological perspective, the oblast is situated mainly within the Prydniprovska lowlands, partly in the Central Russian uplands (in the north) and Donetsk uplands (to the southeast). But despite the great potential of the natural complexes and objects, which have special nature conservation, scientific, aesthetic, recreational and other values, Kharkiv oblast has one of the lowest levels of nature protection in Ukraine. Only $2.35 \%$ of the oblast is under the protection of the Nature Reserve Fund (NRF), the second lowest proportion in Ukraine, being larger only than Vinnitsa Oblast (2.1\%) (Nature Reserve Land of Kharkiv oblast, 2016). The protection of so called inanimate nature, which is understood as objects of geological heritage which are important components of the Nature Reserve Land, is no better than that of biologically valuable sites.

On 1.04.2015, Kharkiv oblast was considered to have 242 territories and objects of NRL with a total area of 74.15 thousand ha. Similarly to other Ukraine regions, Kharkiv oblast confirmed the "Programme of Forming the National Ecological Complex for 2002-2015", which included analyzing, improving and developing the Ukrainian law according to the recommendations of the European strategy of protecting biological and landscape diversity for formation of a European ecological complex as a single space system of European countries' territories with natural or partially altered landscapes (Manyuk Vad. \& Manyuk Vol., 2010). Adopting the Law of Forming Ukraine's Ecological Complex in 2000 had fundamental significance for the development of relations within society for preserving, restoring, protecting the single territorial functional system of territories with natural landscapes, protection of biological and geological diversity and for stable development (Manyuk, 2003).

The necessity of preserving the geological component of the NRF in Ukraine has deep historical roots - from 1910, after the establishment of the Khortytsa Society of Nature Protection, the first such society in prerevolutionary Russia, to 1991 after the foundation of the European Association for the Conservation of the Geological Heritage (ProGEO). After its establishment in Europe, nature protection communities all over the world began to place geological diversity on an equal footing with biological diversity (Manyuk, 2005, 2006). The ruination or destruction of rare rocks and mineral outcrops, remains of fossil fauna and flora, manifestations of glacial activity, signs of volcanism, or other evidences of the history of geological development, will lead to the irreversible disappearance of unique objects which took millions and billions of years to develop, but which can be destroyed instantly. Trees can be replaced with new ones, but geological objects cannot be renewed, therefore they become lost to humanity forever (Manyuk, 2007, 2014).

Presentation of the general material. The geostructural location of Kharkiv oblast provides good prospects for discovering and protecting the objects of geological heritage. The territory of the oblast is situated within the juncture of the Dnieper-Donetsk depression with the Donetsk fold structure in the southeast and the Voronej anteclise in the north. Therefore, its structure is developed by a complicated complex of deposits in a wide stratigraphic range (Gurskyi \& Kalinin, 2011). The Precambrian rocks and Paleozoic rocks lie deep, but due to salt tectonics within Petrivskyi and Krasnooskolskyi diapirs, terrigenous coal outcrops of Devonian and bituminous coal systems appear on the surface. An important role in developing the geological structure of the region was played by the Mesozoic and Cainozoic deposits, which now have more than one outcrop. They are an important part of the natural and artificial outcrops (Fig. 1).

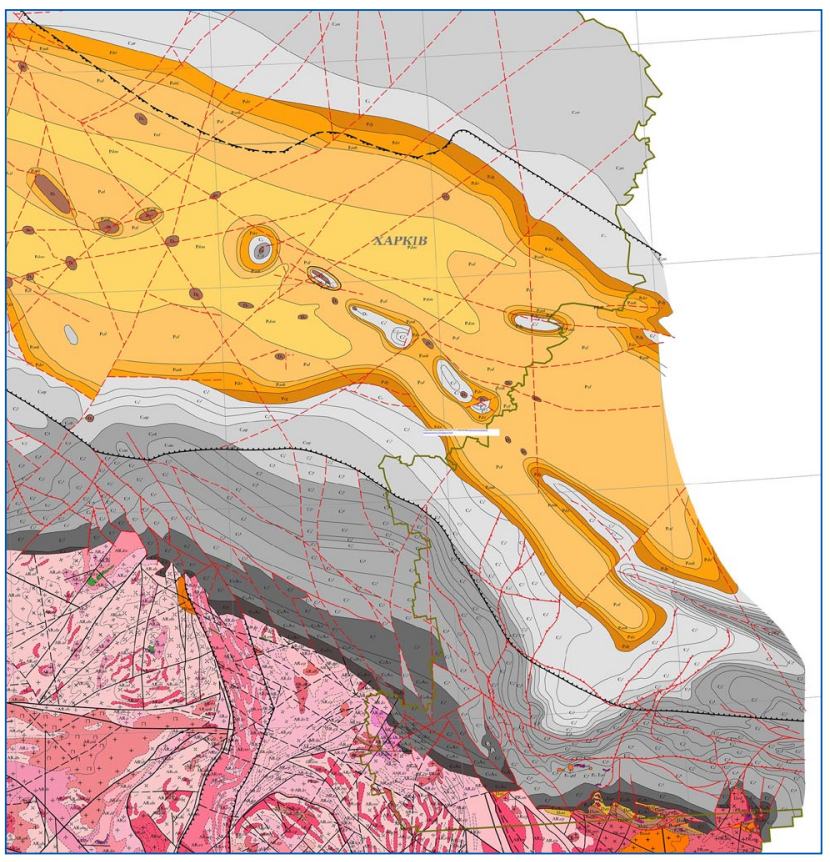

Fig. 1 Pre-Mesozoic map. 
But this is only the potential, i.e. the variety of potential objects of natural geological heritage which have never been included in the official register of natural heritage. Currently Kharkiv oblast has only one object of geological heritage included in the NRL - the Protopopivskyi Geological Reserve of Local Significance. The resolution of the Rada (Council) of Kharkiv oblast of 17.11.1998 provided protection for an area of 14.6 ha which has protected natural outcrops of carbonate rocks of the Middle and Upper Jurassic, exposed by the Ploska Vodiana ravine and a small quarry in Protopopivka village (Leonenko, Stetsenko, and Wozniak (2003). The excellent paleontological quality of the limestone of the Izium and Donetsk Jurassic rock formations (Callovian, Oxfordian and Kimmeridgean stages), corals, brachiopods, Echinoidea and other fossil fauna allows one to consider this reserve a paleontological natural relic of stratigraphic value (Kosmachova, 2008).

According to the results of the revision of research of geological monuments (geosites) of Ukraine, which the author conducted in 2003-2004 as a part of the project of the State Geological Service of Ukraine, 23 geosites (including the Protopopivskyi reserve) were identified in Kharkiv oblast. The time limits of the study did not allow full evaluation of the oblast's geological heritage, therefore this list includes only $50 \%$ of the geological monuments that are worth being protected. Using the results of the study, the 4 volume edition "Geological Heritage of Ukraine" in Ukrainian and English (Gurskyi \& Kalinin, 2011) was published. The fourth volume covered 19 of the 23 studied geosites with correction of mistakes made during publication. The object «Zavodski Hutory» is mentioned in the book under numbers 11 (incorrectly marked) and 19 (rock outcrops of Upper Jurassic limestone near the DniproDonbass Canal). Everything is fine with its position on the map, but these are the abovementioned "Zavodski Hutory". It should be mentioned that unlike the objects situated on Ukrainian shield and which are represented correspondingly, mostly by hard crystalline Precambrian rocks, the geological monuments of Kharkiv oblast are mostly composed of loose sedimentary deposits, which are especially vulnerable to contemporary geological processes and have a short lifespan. Apart from the crumbling of fragments, landslides, blocking by dealluvialproluvial sediments, erosional wash-out, the influence of technical loading, the process of clearing, excavating, and renewing a geosites is becoming impossible due to the growth of brushwood on the sections.
- Ilmenite placer deposit in the Romanovi Rovtsi tract near Nyjniy Bishkin village in Izium district.

- The location of silicified wood in Savyntsi urbantype village in Balaklava district.

- The outcrops of rocks of Beretska rock formation with osseous breccias in Kniazove tract between villages Nyjniy Bishkin and Suha Homolsha in Zmiiv district.

- The outcrops of Beretska and Mejyhirska rock formations in Kruhlyk ravine in the town Zmiiv.

- The outcrops of sandstones of the Kharkov geoseries in Kamyana Yaruha village in Chuhuyev district.

- The outcrops of Sarmatian layer rocks near Haydary village in Sahnowshyna district.

- The stepped fault on the slope of Monastyrska mountain in Haydary village in Zmiiv district.

- The Gotvald fault on the right bank of the Siverskyi Donets river near Zmiiv town.

- Section of Novoharkivska terrace in Buzynna ravine in Velyka Komyshuvata village in Barvynkivka district.

Out of 34 objects of natural heritage described in the guidebook "Geological Heritage of Ukraine" (Zaritskiy \& Schyrytsia, (Eds.) 1985) including those that were recommended to be excluded and those which were included in the updated data base (Gurskyi \& Kalinin, 2011), there are 9 more objects worth being included in NRL of Kharkiv oblast. The list of significant geological monuments can be enlarged by 8 important geosites included in the list, which were proposed by the leading researchers into the geological heritage of Kharkiv oblast, V I Kosmachov and M G Kosmachova, as monuments of national significance, and also the Chepilski Chalk Rocks and the Novomlynski Chalk Hills (Dvorichenski), which are not mentioned in any of the given sources, but which are becoming popular tourist routes (Lunyachek A. Encyclopedia of Travels. 2011). Therefore, Kharkiv oblast has only a single protected geological relic, but a number of potential geosites, which contains 40 objects of local and national value. Creating a unified register which would cover the full geological variety of Kharkiv oblast, bringing together information from scattered sources, requires providing a brief characteristic of the geological monuments of different categories and different types, obtained from the results of revised study and with the revisions mentioned above.

This is also necessary because the "Geosites" international project is not yet completed, therefore selection of geosites for the European list requires updated 
and exhaustive information about the geological heritage of Ukraine (Wimbledon, 1997). The register is divided into three parts according to the possible category of conservation: local, national, and international value.

\section{- Geosites of local level}

- The outcrops of Sarmatian stage near Dar Nadiya village in Sahnowshina district. In a small quarry a section of loess alternation and fossils of Neopleistocene upper layers $(7.5 \mathrm{~m})$ and cross-bedding quartz sands of the middle Sarmatian substage $(5.3 \mathrm{~m})$ with carbonate and flint concretions have been excavated (Fig. 2).

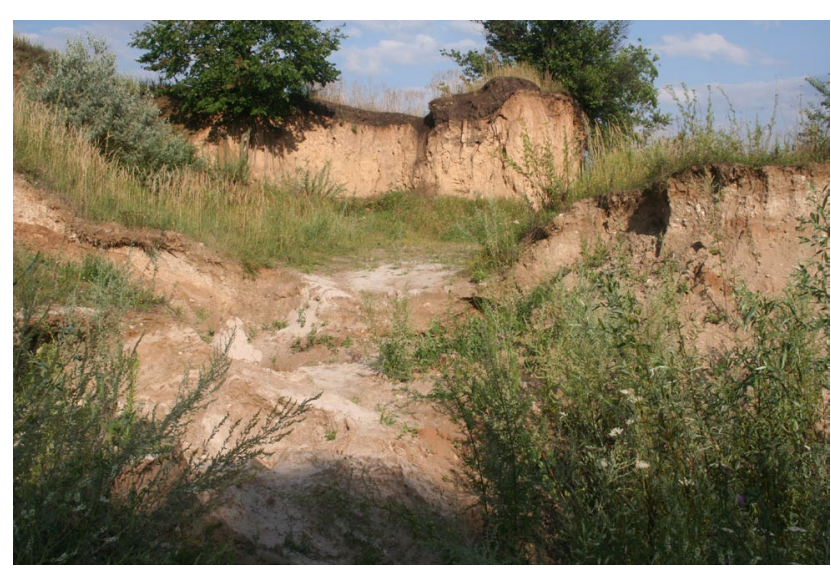

Fig. 2 Outcrops of Sarmatian stage.

- The Triassic outcrop on the right slope of the Siverskyi Donets river in Barvinkivka district, 3.5 $\mathrm{km}$ to the west of Zavodski Hutory village. The small quarry has outcrops of dark-grey claystone-like clay with imprints of Mollusca and poor grade quartz sands of 4-5 m depth (Fig. 3).

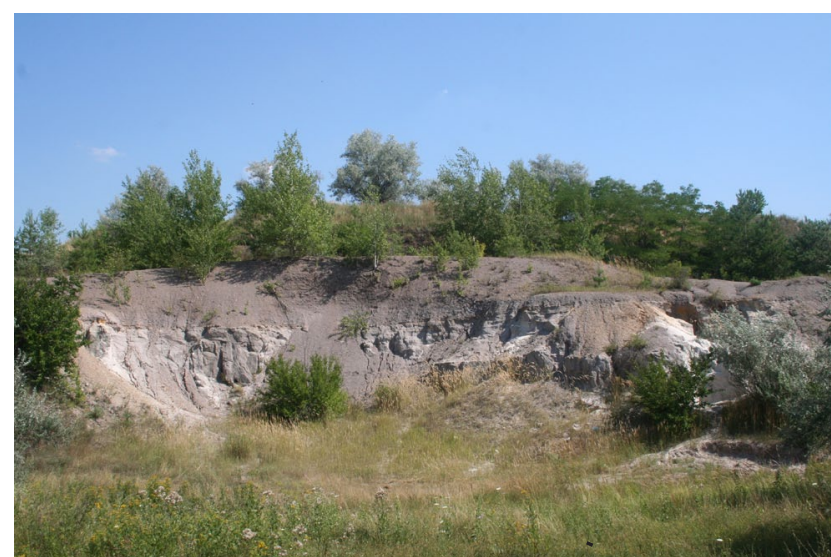

Fig. 3 Triassic outcrop on the right slope of the Siverskyi Donets.

- The Paleogene outcrop in Malolitky village in Barvinkivka district. Two quarries, which are located close to each other, have a section of Novopetrivska suite of Neogene formation $(6 \mathrm{~m})$ and glauconite - quartz aleurites of the Mejihirska suite of Oligocene rock formation (to $9.0 \mathrm{~m}$ ) with interlayers of siltstones.

- The outcrop of Syvaski layers "Artamanovi Rovtsi" in Pershotravensk district near the south edge of Verhniy Bishkin village. The abandoned quarry has a key-bed section of base rock formation $(5.2 \mathrm{~m})$. Between thick interlayers of clay among sands of Suvaski layers, internal molds and fossil imprints of Mollusca typical of the early Miocene period have been found.

- Knaje Urochishe. The outcrop of Beretska and Mejigirs 'ka sutes in Zmiiv district near Nyjniy Byshkin. The outcrop of the contact of Syvasiki sand $(4.6 \mathrm{~m})$ with aleurites of the Oligocene Mejigirs 'ka suite $(6.5 \mathrm{~m})$.

- The Chervonooskol salt dome fold. Together with Lysychansk, Kremensky and Torsky, it belongs to the Lysychansk-Volvenkivska anticline-flexure. The steep slopes of the Bahtyn river's left bank have small but scientifically valuable fragmented sections of different ages: Upper Triassic sandstones, aleurites and mottled clay of the Upper Jurassic Protopopiv suite, chalk, etc.

- The Petrivskyi salt dome. The Petrivskyi dome in Orlova ravine in Petrivka village in Balakliyskyi district brought to the surface outcrops which contain rocks of coal systems. (Pitkovska, 1940) (Fig. 4).

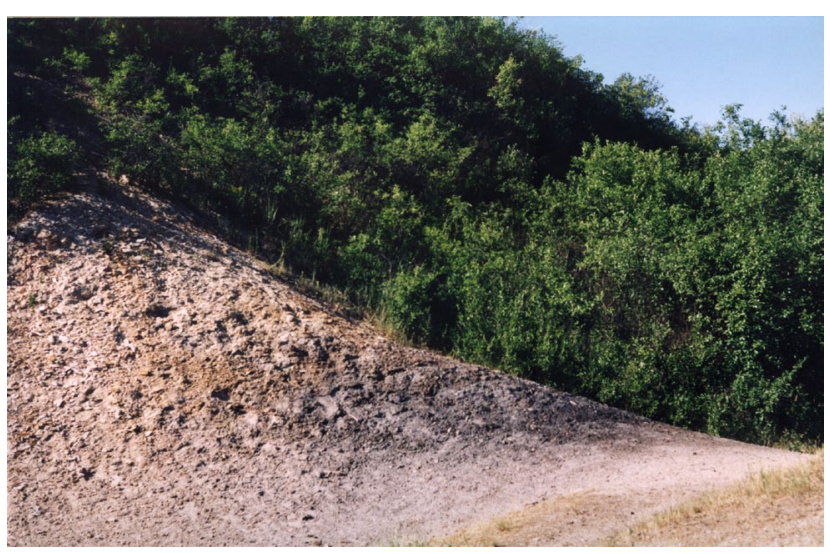

Fig. 4 Outcrop of coal «Petrivskyi dome».

- The Donetsk ancient settlement site near Karachevka village (Kharkiv district of Kharkiv city). The picturesque hill on the high bank of the Uda river is considered to be the location of ancient Kharkiv, which was destroyed by the Tatars in the XIth century. The steep slope has outcrops of the Peryaslavsk-Cherkasy terrace, covered by the layers of loess horizons and excavated soils of Pleistocene upper layer (Fig. 5).

- The Paleogenic outcrop in Bilohorodska Street in Kharkiv. It is a wonder that this historically valuable outcrop of glauconite-quartz aleurites of Oligocene Mejihirska suite has survived to the present. In this place, M P Barbot de Marni in 1870 described for the 


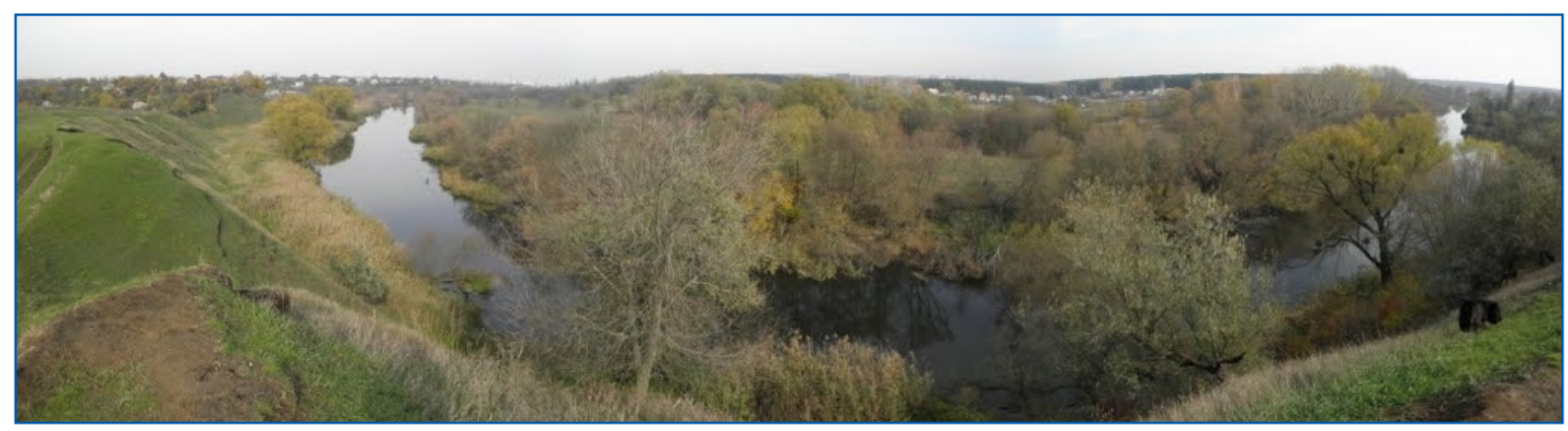

Fig. 5 Donetsk ancient settlement on the bank of the Uda river.

first time in modern science "the Kharkiv group of rocks", which included all rocks from the Kyiv suite to the Mejyhirs 'ka suite.

- The outcrop of Poltavska geoseries rocks in Yar Pechenyk near Vysoke village. The small quarry has an outcrop of a section of Beretska suite within Syvaski (white fine-grained cross-bedding sands) and Zmiyevski (grey clayey sands with coaled vegetative detritus) layers.

- The Paleogene outcrop and Upper Cretaceous in the area between the villages of Piyatyhirske and Kreydova (Milova). The precipice of the high bank of the Siversky Donets has an outcrop of glauconite sands of the Kharkiv geoseries, marl of Kyiv suite, greenishgrey sands of the Buchatska geoseries and white chalk.

- The outcrop of Paleogene rocks on the right bank of the Siversky Donets river near Zalyman village in Balaklavsky district. The precipice contains a $30 \mathrm{~m}$ high outcrop of rocks that belong to the Kharkiv geoseries, the Kyiv suite and the Buchatska Paleogene geoseries with remains of crabs and phosphorite concentrations.

- The outcrop of Burhanivka sandstones in the steep bank near Burhanovo village in Izium district. It contains outcrops of quartz cross-bedding sands and grey clays of the Lower Jurassic Toarcian layer with lenses of ochre and reddish-brown clays.

- The outcrop of Middle Jurassic Bayos stage near Donetske village in Izium district. The slope on the right shore of Siverskyi Donets has outcrops of greenish-grey lake clays with vegetative detritus and grey marine clays with typical zonal ammonites, with interlayers of sandstones and siderite lenses and noddles.

- A section of Paleogene deposits on the right bank of the Suhyi Torets river in Barvinkove. This is the location of outcrops of gravelstones of the Pliocene Marfinska rock formation, deposits of the Paleogene Beretska, Mejyhirska, Obuhivska, Kyivska and Buchats 'ka suites.

- The outcrop of volcanic ashes in Solonetska ravine in Izium district near Levkivka village. The ash interlayer lies in the loam of the Upper Neopleistocene layer at the depth of $1.5-2.0 \mathrm{~m}$.

\section{- Geosites of national significance.}

- The outcrops of Quaternary deposits, rocks of the Kyivska and Obuhivska suites in the Krutyi Log ravine bank in the north part of Ruski Tyshky village in Harkivsky district. The Quaternary section has a layer of volcanic ashes, the rocks of Kyiv suite contain the remains of fossil fauna and nodules of phosphorites, it is in contact with Upper Cretaceous deposits.

- Typical Paleogene section in Kruchi tract within the watershed line between Kruhlyk ravine and the Siversky Donets river at the south edge of Zmiiv city. Apart from having outcrops of rocks of Beretska, Mejyhirska and Obuchivska suites, and a section of Quaternary deposits, the tract is exceptionally picturesque and has great historical value. Since the XIXth century the tract has been the site of research by N D Borysiak, M O Sokolov, P Y Armashevskyi, D M Sobolev, I M Remizov and others (Fig. 6).

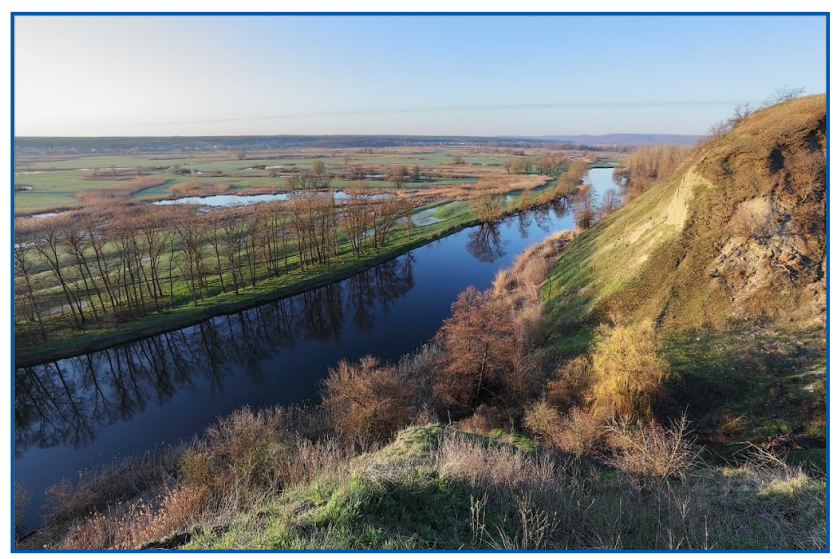

Fig. 6 Paleogene section in Kruchi tract.

- Horodyshchenska mountain. Stratotype of Zmiyevski layers of Beretska suite near Haydary village in Zmiiv district. On the right bank of the Siversky Donets river, $5 \mathrm{~km}$ south-east of Haydary village, between Snytkovy ravine and Siversky Donets, in a high shoreline 


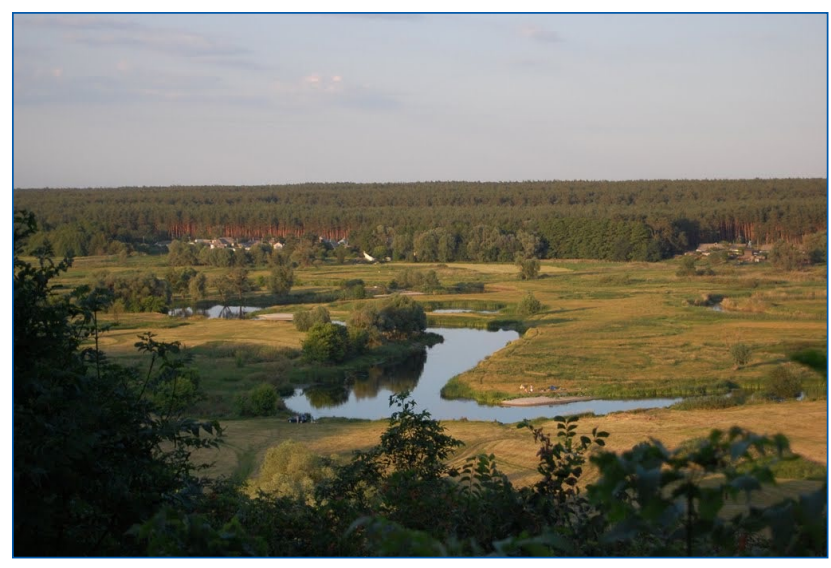

Fig. 7 Landscape of Horodyshchenska mountain.

ravine, there is a typical section of Zmiyevski layers of Berets 'ka suite with remains of fossil plants. This outcrop is recognized as one of the most valuable paleobotanical objects in the world (Koval, 1939) (Fig. 7)

- Kozacha Hora. On the windings of the Siversky Donets, on the steep right slope, $0.8 \mathrm{~km}$ south of Koropovo village in Zmiyevsky district, there is a practically complete Eocene and Oligocene section within the Zmiyevski and Syvaski layers of the Beretska, Mejuhirska and Obuhivska suites. There are also valuable interlayers of "osseous breccias", findings in 1909 Eocene cetaceans Zedlodon rossicus Paulson (Remizov, 1954) (Fig. 8).

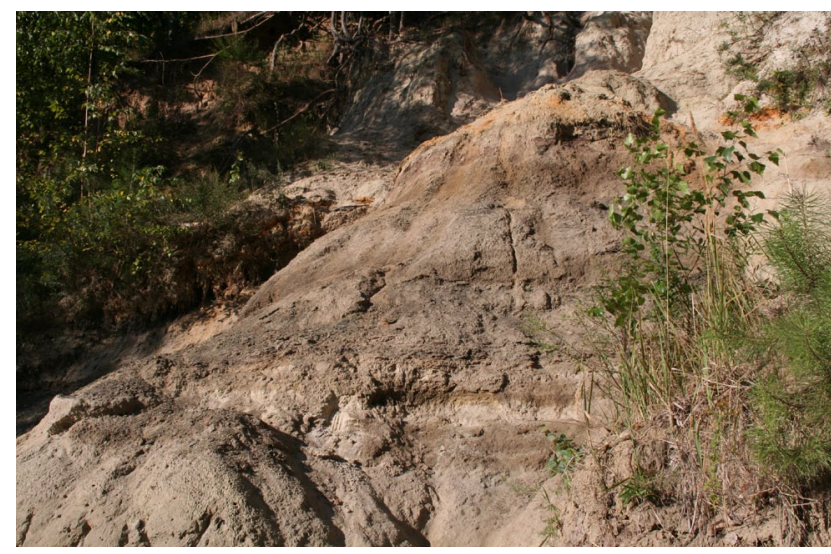

Fig. 8 Kozacha Hora. Oligocene section.

- Stratotype of Syvaski layers. The abandoned quarry on the right slope of Bereka river between villages Oleksiyovka and Syvash in Pershotravensk district has a significant sectional fragment of Zmiyevski and Syvavski layers of the Berekska suite. Here, in 1947, for the first time in the study of the Poltavsky stage, the geologist Y B Chuyko found remains of Mollusca in Syvavski sands (Fig. 9).

- Balaklavsky typical section of Upper Cretaceous and Paleogenic deposits. The extensive active quarry

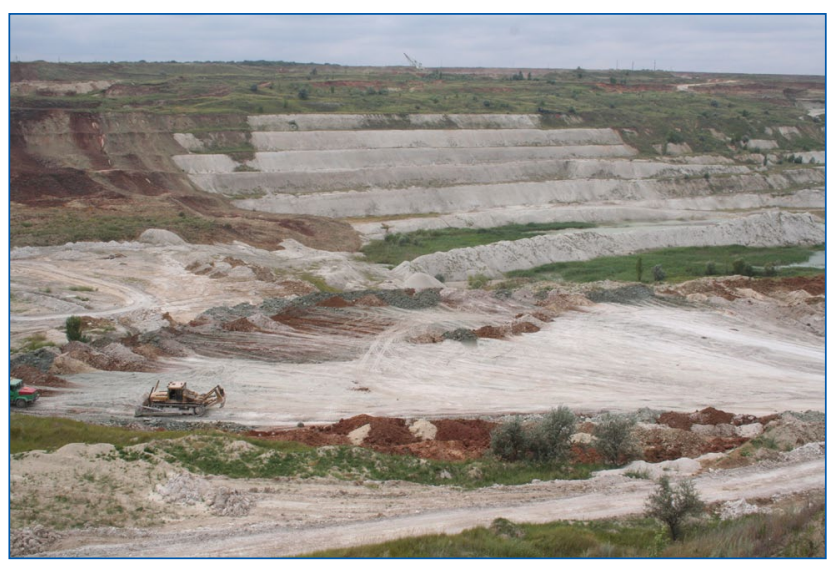

Fig. 9 Outcrops of white chalk in active quarry.

near Kreydova village has outcrops of white chalk from the Santonian, Campanian and Maastrichtian stages of the Upper Cretaceous, sectional fragments of the Paleogene and Quaternary systems.

- Grekovsky karst. The outcrops of Jurassic deposits in the abandoned quarry in Grekove tract. There are also outcrops of cavernous Upper Jurassic with niches of leaching, sink holes and wells near the abandoned Perekop village in Izium district.

- Upper Jurassic Smyrnivsky key bed section in Smyrnivka village in Lozovatsky district. The abandoned quarry of the sugar plant has outcrops of chemogenic cavernous limestone of Callovian, Oxfordian and Kimmeridgean stages with a great variety of Mollusca fossil fauna. The large territory of the quarry is extended by the Nelubivska ravine, which is a watershed of the Brytay river. Also there are Paleogenic section fragments from the Buchackska geoseries to the Bereckska suite (Kosmachova, 2008, Smerdov, 1948) (Fig. 10, 11).

- Protopopivske outcrop of Jurassic and Paleogene rocks. A geological reserve with an area of 14.6 ha in the middle of the Ploska Vodiana ravine to the north of Protopopivka village in Balaklia district has an outcrop of good paleontologically rich oolitic limestone of Oxfordian, Kimmeridgean and Tithonian stages and gravelstone and sandstone of Callovian stages of the Middle Jurassic period (Kuzmicheva \& Makridin, 1962).

- Zavodski Hutory tract. In the pre-shore part of the Siversky Donets valley, in Zavodski Hutory tract near Zavody village in Izium district, in an abandoned quarry, there are outcrops of kaolin Lower Cretaceous sandstones, colourful mottled rocks of the Kimmeridgean and Tithonian stages of the Upper Jurassic with Nerinea sp., Turbo sp., Pecten sp. and oolitic limestone of Kamianska suite of the Upper Jurassic Batsky stage (Fig. 12).

- Harajivske outcrop of Late Triassic flora $3 \mathrm{~km}$ to the north of Komyshuvata village in Barvinkivsky 


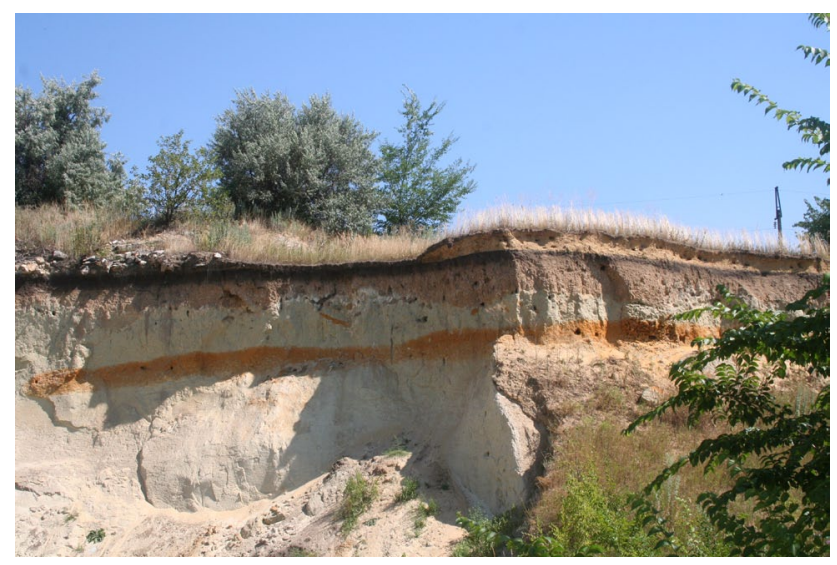

Fig. 10 Smyrnivsky section. Paleogene.

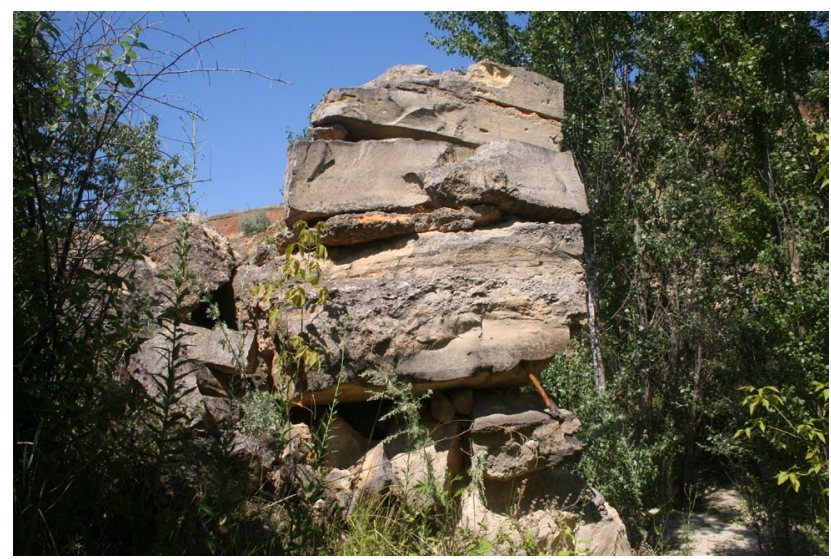

Fig. 11 Upper Jurassic Smyrnivsky section.

district, at the foot of the right bank slope of the Siversky Donets river, which has numerous steep banks. The clay of Upper Triassic Protopopivska suite has numerous remains of leaves, branches, reproductive organs of plants and imprints of insects.

- The Upper Jurassic outcrops on the east edge of Kamianka village in Izium district. On the right shore of the Siverskyi Donets river, $1 \mathrm{~km}$ downstream from the mouth of the Hrekivka river, there are outcrops of

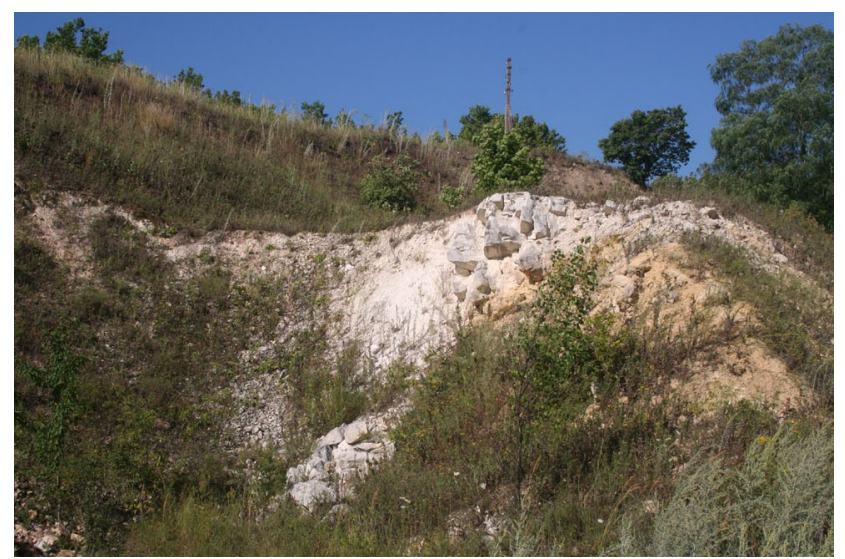

Fig. 12 Outcrops of Lower Cretaceous sandstones and rocks of the Upper Jurassic.
Izium suite with ammonites Perisphinctes sp., which are typical of the Middle Jurassic.

- The Cainozoic outcrops in a quarry near Novoselivka village in Novovodolazke district. An open section of Quaternary deposits with interlayers of volcanic ashes, reddish-brown clays, Pliocene, Novopetrivska suite and Syvavski layers of the Berekska rock formation (Segeda, 2007) (Fig. 13).

- The Middle and Upper Jurassic outcrops in Chervony Yar tract near the south-west edge of Izium town. The steep canyon-like tract on the south side of Kreminets mountain has paleontologically rich deposits of Jurassic Izium and Donetska suites with a great variety of lithological compounds.

- The Upper Jurassic outcrops near Mala Komyshuvata village in Izium district. On the left bank of Malokomyshuvatska ravine, in an abandoned quarry, there are outcrops of oolitic limestones of Oxfordian and Kimeridgean stages with numerous fossil Mollusca, Echinoidea and ammonites (Stanislavskiy, 1976).

- The Middle Jurassic outcrops near the former hamlet Shevchenko near Kamianka village in Izium district. On the shore line of Siversky Donets river, erosion has exposed a Middle Jurassic section, which is a parastratotype of the Kamianska rock formation of

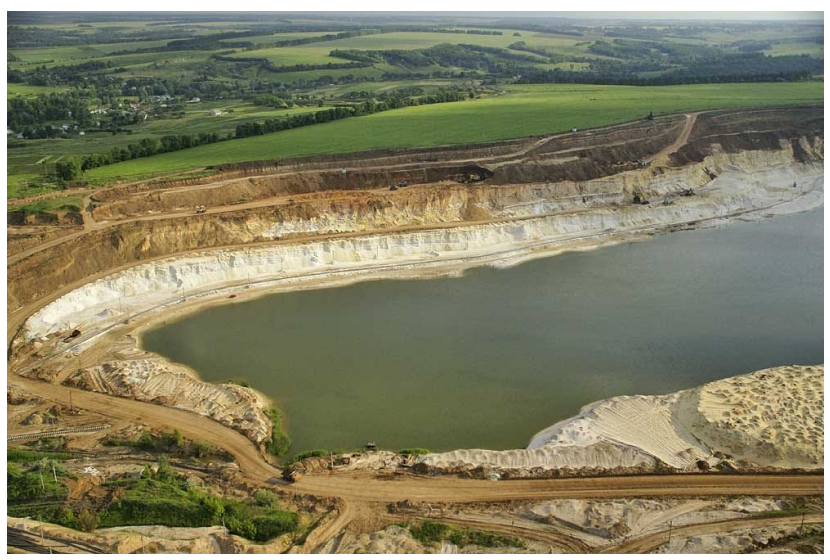

Fig. 13 Novoselivka quarry.

Batsky stage with remains of fossil fauna, first described in 1898 by G G Tomas, the curator of the Cambridge University Botanical Museum.

- The Middle and Upper Jurassic and Cretaceous outcrops in Suhokamianska ravine near Suha Kamianka village in Izium district. The steep banks on the right slope of the ravine have fragmental outcrops of: stratotype of Kamianska rock formation (Batsky stage), parastratotype of Middle-Upper Jurassic Izium and Donetska rock formations, section of Kremenetska Upper Cretaceous with remains of fossil fauna and flora.

- The outcrops of the Cenomanian stage of the 
Upper Cretaceous near Yaremivka village in Izium district. The abandoned quarry on the left slope of a big ravine has outcrops of silicified sandstones and Zavodska rock formation of Albian stage and parastratotype of Kremenetska rock formation of the Upper Cretaceous with various fossil fauna.
- Kamianske outcrop of Jurassic and Triassic rocks near Kamianka village in Izium district. The lower part of the Protopivska ravine and the Krynychna ravine have outcrops of a stratotype section of the Upper Triassic Protopivska rock formation, Kojumenska and Cherkaska suites of Toarcian and Bajocian stages with a high density

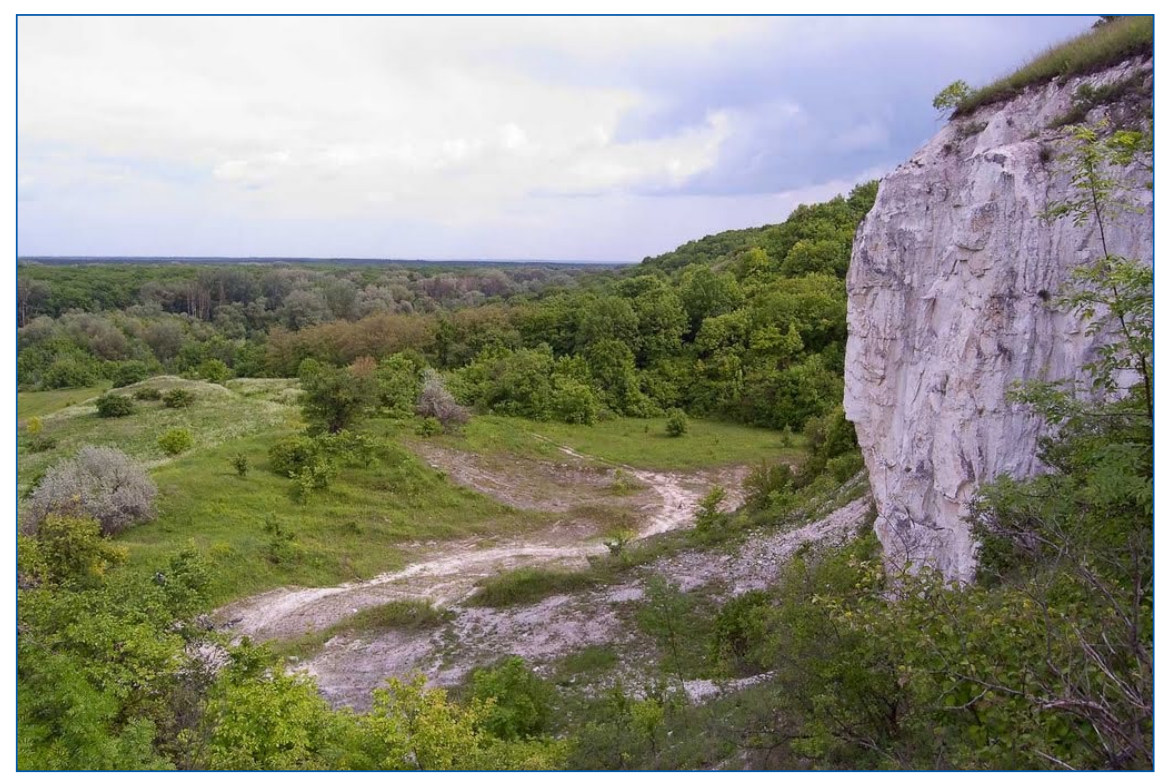

Fig. 14 Outcrops of Upper Cretaceous near Chepil.

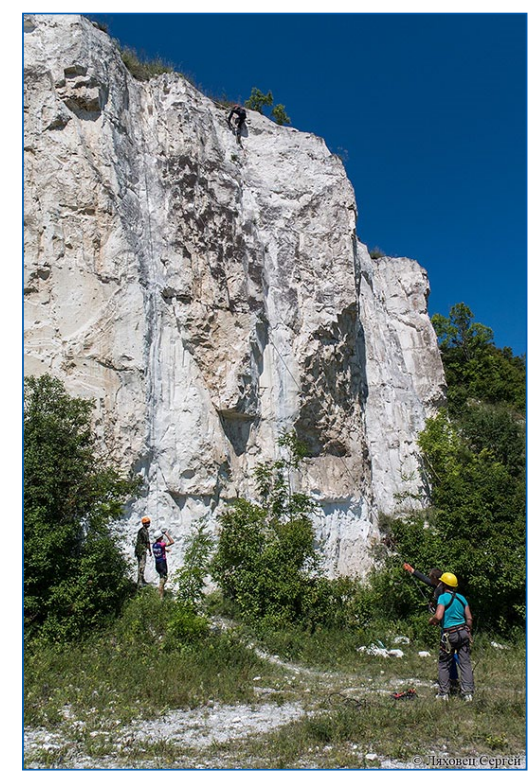

Fig. 15 White rock.

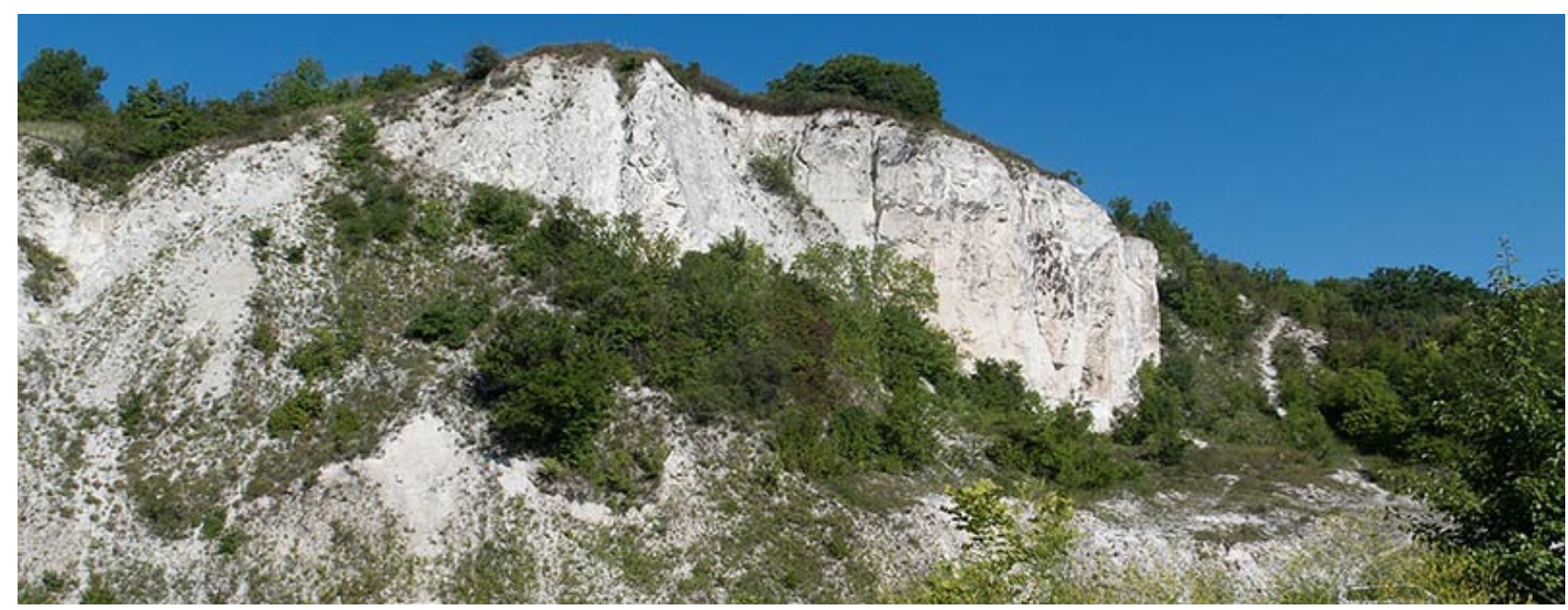

Fig. 16 «Bila skelia» (White Rock) near Chepil stream between Chepil and Protopopivka villages.

- «Bila skelia» (White Rock) near Chepil stream between Chepil and Protopopivka villages in Balakliia district. The high, picturesque rocks $300 \mathrm{~m}$ from the mouth of Chepil stream in an abandoned quarry have $100 \mathrm{~m}$ long outcrops of Upper Cretaceous Shyrokynska suite (Turonian and Coniacian stages). There are interlayers and concretions of phosphorites among marl and chalk. Also there is a picturesque canyon near the quarry. The canyon and the quarry's rocks are good objects for tourism (Fig. 14, 15, 16). of fossil fauna and flora, which have been studied by leading paleontologists since the late XIXth century.

- Geosites of international value (object which are promising for the European list).

- Kremenets' mountain. The butte form of relief, which is surrounded on three sides by the Siverskyi Donets river, shows the geological structure of the conjunction area of the Dnieper-Donetsk depression and Donetsk fold structure with its numerous outcrops. It has numerous tectonic manifestations, karstifications, with a variety 


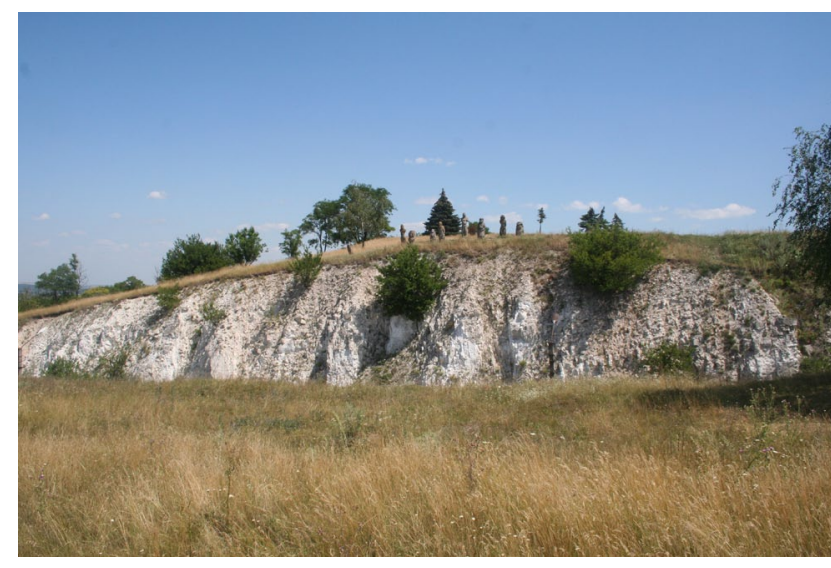

Fig. 17 Kremenets` mountain.

of lithological-face conditions of the development of Jurassic and Cretaceous rocks, with important stratotypes and parastratotypes of many stratigraphic units of the period. Also this is a unique object of geological research O. O. Borysak, I. A. Goldenshtadt, E. P. Kovalevsky, R. I. Murchyson, V. O. Domher devoted their studies to this object. Kremenets mountain is the only place in Ukraine where the remains of the plesiosaur species, Cimoliosaurus bernardi Owen, have been found . (Fig. 17).

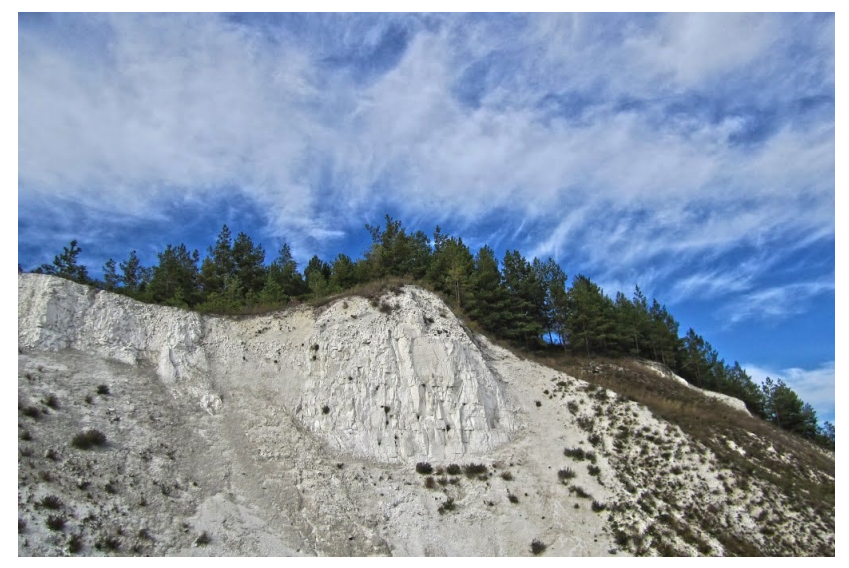

Fig. 18 Vovchanske outcrop of the chalk.

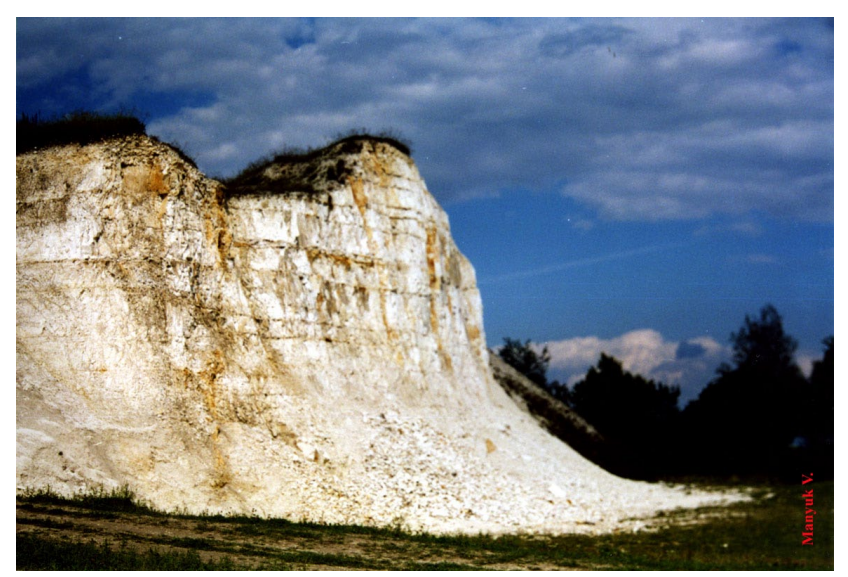

Fig. 19 Outcrop of the Upper Cretaceous.

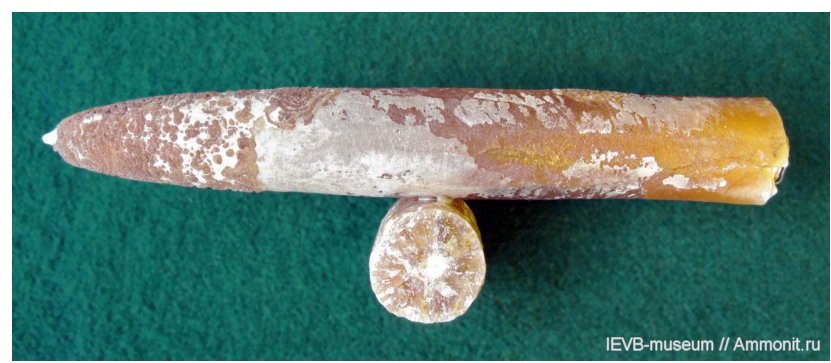

Fig. 20 Belemnitella mucronata (Schlotheim, 1813).

- Hrekivske outcrop. On the left slope of the Hrekivka river, near its confluence with the Siversky Donets, there are outcrops of mottled clays of the Kimeridgian stage of the Upper Jurarrasic, oolitic limestones and limestone-coquina of the Callovian and Oxfordian stages of the Upper Jurarrasic, which are well characterized by the diversity of fossil fauna.

- Vovchanske outcrop of the Campanian and Maastrichtian stages chalk of the Upper Cretaceous on the right slope of the Vovcha river near the village of Tyhe in Vovchansky district. The snow-white chalk mountains, which extend through the Vovcha ravine from Vovchansk to the border of Bilhorodska oblast, form a unique object for creating the first geopark in the north of Kharkiv oblast (Manyuk, 2006, 2007). (Fig. 18, 19, 20).

- Novomlynski chalk mountains.

On a ledge of the high right bank of the Oskol river, over a length of $33 \mathrm{~km}$, Upper Cretaceous deposits are exposed in numerous steep banks and erosion wash-outs, practically as a single, unified outcrop. They create a unique landscape and have great scientific value.

The Chalk Mountains are one of the main objects of the "Dvorichansky National Natural Park", which was created in 2009 expressly for the purpose of conserving these unique chalk mountains and their flora. In the XVIIIth century, a leading Ukrainian geology researcher

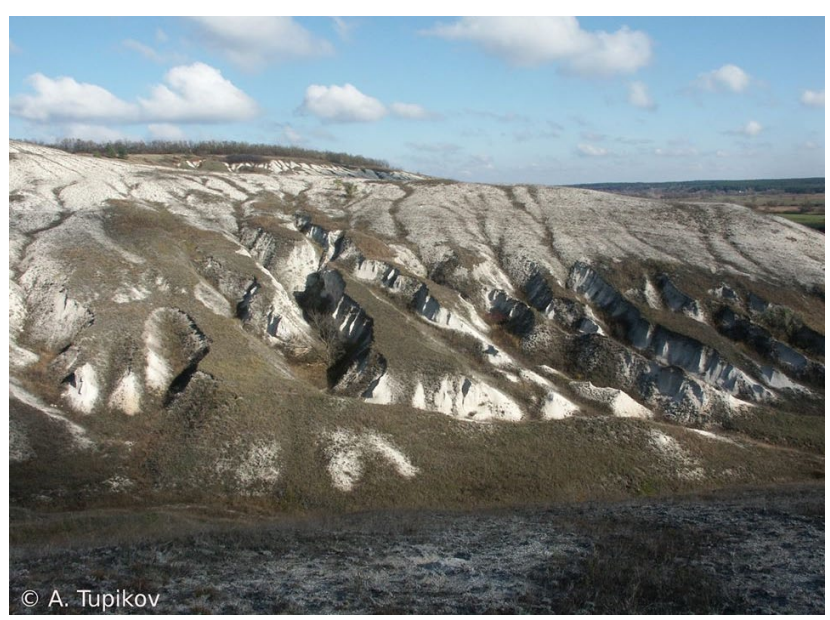

Fig. 21 Dvorichansk National Natural Park. 
Petro Palas emphasized on the necessity of conservation of the Chalk Mountains and their flora.

Conclusions. The peculiarities of the geological formation of Kharkiv oblast, the relief and general distribution of sedimentary rocks, make it imperative to conduct regular monitoring of the objects of its geological heritage. In the considered list of geosites, 9 out of the 49 geological monuments are recommended to be excluded since they do not correspond to the criteria of the general register. We recommend 16 monuments of local value, 20 of national value, and 4 to be included in the European list. Among other problems, the main problem of conserving the geological heritage of Kharkiv oblast is to solve the problems connected with conferring conservation status on the selected objects. This includes writing an application about the necessity of protecting each newly recommended object of the NRL and presenting it to the Ecology Department of Kharkiv oblast. The application must include the appropriate scientific descriptions and cartographic materials and, following this, observance of the procedures for obtaining consent for the conferring of conservation status upon an object from stakeholders in the land at local, district and oblast levels. An important precondition for providing a geological object with protected status is recognition by all levels of state administration of the necessity of conservation of biological and geological diversity (Wimbledon, 1997). The concept of geological diversity was incorporated into European nature conservation practice due to the activization of the European Association for the Conservation of the Geological Heritage (Pro $\mathrm{Geo})$, the increase in its authority around the world, realization of the necessity of conservation of inanimate nature and development of methodological programs for protecting biological and landscape diversity (Wimbledon \& Smith-Meyer (eds), 2012). The problem of conserving biological and landscape diversity should be seen as a multilevel process, which includes legislative, scientificmethodological, socio-economic support for the programs and measures in the nature conservation sphere (Zinko, 2004).

\section{References}

Alexandrowicz, Z., Poprawa, D. (Eds), 2000. Geodiversity conservation of the Polish Carpathians (with map 1:400 000). Panstw. Inst. Geol., Warsawa, 142 p. (in Polish).

Borisyak, A.A. 1905. Geologicheskij ocherk Izjumskogo uezda i prilezhashhej polosy Pavlogradskogo i Zmievskogo uezdov. [Geological essay of Izyum district and adjacent bands Pavlograd and Zmiev counties]. Proceedings of Geol. Committee, the new series. 3, 344p. (in Russian). Fedorovskiy, A. 1912. Nahodka iskopaemogo kitoobraznogo v Zmievskom uezde Har'kovskoj gubernii. [Finding in the fossil cetacean in Zmiev county of Kharkov province]. Kharkov: Typography M.H. Sergeyev and K.M. Kalchenko, 42 p. (in Russian).

Gurskyi, D.S., \& Kalinin V.I. 2011. Geologichni pam'jatky Ukrai'ny. [Geological landmarks of Ukraine]. Kyiv, 4, 205-260 (in Ukrainian \& English).

Kosmachov, V.G. 2005. Izuchenie geologo-geograficheskih pamjatnikov prirody kak odno iz napravlenij regional'nyh issledovanij v Har'kovskom universitete. [Study of geological and geographical monuments of nature as one of the directions of regional studies at Kharkov University]. Bulletin of Kharkiv National University: Geology. Geography. Ekology. 655(31), 48-51 (in Russian).

Kosmachov, V.G., Kosmachova, V.G. 2010. Geologichni naukovo-osvitni ekskursii' po Harkivshhyni. Paleozojs'kyj geotur. [Geological research and educational tour of the Kharkiv region. Paleozoic geotour]. Bulletin of Kharkiv National University: Geology - Geography - Ecology, 909(32), 32-37 (in Ukrainian).

Kosmachov, V.G., Kosmachova, V.G. 2011. Geologichni naukovo-osvitni ekskursii' po Harkivshhyni. Jurs'kyj geotur. [Geological research and educational tour of the Kharkiv region. Jurassic geotour]. Bulletin of Kharkiv National University: Geology - Geography - Ecology. 956(34), 32-37 (in Ukrainian).

Kosmachov, V.G., Kosmachova, V.G. 2012. Geologichni naukovo-osvitni ekskursii' na kajnozojs'ki ob'jekty Harkivshhyny. [Geological research and educational excursions to Cenozoic objects of Kharkov Region]. Bulletin of Kharkiv National University, Vol. 36, 997: Geology - Geography - Ecology, 38-43 (in Ukrainian). Kosmachova, M.V. 2008. Geosajty Harkivshhyny, i'h racional'ne vykorystannja ta ohorona. [Geosites of Kharkiv, their rational use and conservation]. Author. thesis for obtaining sciences degree candidate of geograph. sciences: specials. 11.00.11 "Constructive geography and rational use of natural resources." Kharkiv, 22 p. (in Ukrainian).

Kosmachova, M.V., 2010. Geologichni naukovo-osvitni ekskursii' po Harkivshhyni. Triasovyj geotur. [Geological research and educational tour of the Kharkiv region. Triassic geotour]. Bulletin of Kharkiv National University. 924(33), Geology - Geography - Ecology, 40-44 (in Ukrainian).

Kosmachova, M.V., 2011. Geologichni naukovo-osvitni ekskursii' na krejdovi ob'jekty Harkivshhyny. [Geological research and educational excursions to the Cretaceous sites of Kharkiv]. Bulletin of Kharkiv National University, Geology - Geography - Ecology. 986 (35), 33-37 (in Ukrainian).

Koval, J.M. 1939. Pro nyzhn'opoltavs'ki shary v rajoni m. Zmijova (zamitka pro ekskursiju kolektyvu instytutu geologii' HDU do rajonu m. Zmijova). [About Lower Poltavske layers in the vicinity Zmiyov (A note on Geology Institute staff tour of KSU to district of Zmiyov)]. Scientific notes Kharkov University. West. Institute of Geology, 16 (7), 243-250 (in Ukrainian). 
Kovalev, P.V., Remizov, I.N., Prohodsky, S.I. 1975. Nahodky vulkanycheskogo pepla v okrestnostjah Har'kova. [Findings of volcanic ash in the vicinity of Kharkiv]. Guide of excursions of the III Congress of the Geographical Society of the USSR. Kharkov: Oblpoligrafizdat, 3844 (in Russian).

Kuzmicheva, E.I. Makridin, V.P. 1962. Novye dannye o kolonial'nyh korallah verhnejurskih otlozhenij severozapadnoj okrainy Doneckogo skladchatogo sooruzhenija [New data on the colonial corals Upper Jurassic the north-western outskirts of Donetsk folded structure] Notes of the Geol. Department KSU. 15, 112-131(in Russian).

Leonenko, V.B., Stetsenko, M.P. Wozniak, Y.M. 2003. Atlas ob'jektiv pryrodno-zapovidnogo fondu Ukrai'ny. [Atlas of Nature Reserve Lands of Ukraine]. Publishing and printing center "Kyiv University," 94-98 (in Ukrainian).

Lunyachek, A. 2011 Encyclopedia of Travels. Retrieved from http://www.encyclopedia-stranstviy.com/2011/07/blogpost.html.

Manyuk, Vad. V. 2003. Propozycii' do proektu Programy formuvannja nacional'noi' ekologichnoi' merezhi Dnipropetrovs'koi' oblasti na 2003 - 2015 roky. [Proposals to the draft Program of national ecological network of Dnepropetrovsk region in 2003 - 2015 years]. Coll. «Problems of Nature Reserve Lands of Dnipropetrovsk region and ways of attracting young people to address it.» Dnipropetrovsk, 90-92 (in Ukrainian).

Manyuk, V. 2005. Preservation of the geological heritage of Ukraine: new steps towards the creation of a database of geosites. Uppsala, Sweden, ProGEO NEWS. 2, 1-8.

Manyuk, V. 2006. Potential objects for creation of a Network National Geoparks in Ukraine. ProGEO Symposium "Safeguarding our Geological Heritage." Kyiv Kamianets-Podil'sky, 30-32.

Manyuk, V. 2007. The problem of creation of Network National Geoparks in Ukraine. Dnipropetrovsk. Bulletin DNU, 63-67.

Manyuk, V.V. 2007. Istoricheskij obzor izuchenija geologicheskogo nasledija v Ukraine. [Historical overview of the study of geological heritage in Ukraine]. Proceedings of the Workshop of the Russian group ProGEO. Miass, 47-49 (in Russian).

Manyuk, V.V., Manyuk, Vol. V. 2010. Pryrodno-zapovidnyj fond Dnipropetrovshhyny. [Nature Reserve Lands of Dnipropetrovsk]. Training Directory. Dnepropetrovsk, 102-115 (in Ukrainian).

Manyuk, V.V. 2014. Geologichna skladova u formuvanni pryrodno-zapovidnogo fondu Ukrai'ny. [Geological component in the formation of Nature Reserve Lands of Ukraine]. Bulletin DNU series: geology, geography. Dnepropetrovsk, 22 (3), 29 - 33. doi: 10.15421/111404 (in Ukrainian).

Nature Reserve Land of Kharkiv oblast, 2016. Retrieved from https://uk.wikipedia.org/wiki/ Natural Reserve Land of Kharkiv region.
Pitkovska, C.N. 1940. Do pytannja pro pohodzhennja brekchii’ Petrovs'kogo kupola. [On the origin of breccia Petrovsky dome]. Geol. Journ. VII (3), 221-226 (in Ukrainian).

Remizov, I.M. 1954. Geologichnyj narys rajonu derzhavnoi' lisovoi' smugy Zmii'v-Gomil'shans'ka lisova dacha [Geological essay the area of state forest zone ZmievHomilshanski cottage]. Scientific Notes of Kharkov State Teaching Institute G.S. Skovoroda. Geographer. series. XIII, 43-65 (in Ukrainian).

Remizov, I.N. Makridin, V.P. 1952. O facijah verhnejurskih otlozhenij gory Kremenec u g. Izjuma. [About Upper Jurassic facies of the mountain Kremenets near the Izyum town]. Bull. Mosk. of the Society of Naturalists. 57. Dep. Geol. 27(6), 59-68 (in Russian).

Segeda, S.I. 2007. Kompleksne vykorystannja vidprac'ovanyh kar'jeriv u navchal'no-naukovyh ciljah na prykladi Novoselivs'kogo rodovyshha (Harkivs'ka oblast') [Integrated use of disused quarries in teaching and research purposes as an example Novoselovske mineral deposit (Kharkiv region)]. Geography, geoecology, geology: the experience of research. The materials of international scientific conference of students and graduate students. Dnipropetrovsk, 4, 204-208 (in Ukrainian).

Smerdov, N.E. 1948. Jurskie otlozhenija bassejna reki Bereki. [Jurassic sediments of Basin Bereka]. Scientific notes of Kharkov state. Univ. XXVI. Notes. Inst Geology. 9, 50-59 (in Russian).

Stanislavskiy, F.A. 1976. Srednekejperskaja flora Doneckogo bassejna. [Middlekeyperska flora of Donets Basin]. Kyiv, Scientific Dumka, 168 p. (in Russian).

UNESKO Geoparks Programme - a new initiative to promote a global network of geoparks safeguarding and developing selected areas having significant geological features. 1999. Hundred and fifty-sixth Session. United Nations Educational, Scientifical and Culturel Organization: Executive Board. Paris, 1-4.

Wimbledon, W.A.P. 1997. The former GILGES, and the new GEOSITES Project of IUGS/UNESCO. In Look E.-R. (Ed.) Geotopschuttz und seine rechtlichen Grundlagen. Schriftenreihe der Deutschen Geologischen Gesellschaft. $5,20-23$

Wimbledon, W.A.P. \& Smith-Meyer, S. (eds). 2012. Geoheritage in Europe and its conservation. ProGEO, Bristol. 405 p.

Zaritskiy, A.I. \& Schyrytsia, A.S. (Eds.). 1985. Geologicheskie pamjatniki Ukrainy. [Geological monuments of Ukraine]: Directory-Guide. Kiev, Scientific Dumka, 117-122 (in Russian).

Zinko, J.V. 2004. Problematyka georiznomanitnosti u Jevropejs'kyh programah zberezhennja bio- ta landshaftnogo riznomanittja. [Problems of geodiversity conservation European programs in bio- and landscape diversity]. Visnyk Lviv. Univ. Ser. Geogr. 31, 235-240 (in Ukrainian). 